UD Classification: 314.1

\title{
Anthony ORJI
}

Ph.D, Senior Lecturer, Department of Economics, University of Nigeria, Nsukka, e-mail: anthony.orji@unn.edu.ng, ORCID ID: http://orcid.org/0000-0003-4032-7051

\section{Jonathan E. OGBUABOR}

Ph.D, Senior Lecturer, Department of Economics, University of Nigeria, Nsukka, e-mail: jonathan.ogbuabor@unn.edu.ng, ORCID ID: http://orcid.org/0000-0002-0162-0303

\section{Chikaodinaka IWUAGWU}

Researcher, University of Nigeria, Nsukka, e-mail: odinakazuka@gmail.com, ORCID ID: http://orcid.org/0000-0001-9800-1906

\section{Onyinye I. ANTHONY-ORJI}

Ph.D, Lecturer, Department of Economics, University of Nigeria, Nsukka,e-mail: onyinye.anthony-orji@unn.edu.ng, ORCID ID: http://orcid.org/0000-0002-0603-7264

\section{EMPIRICAL ANALYSIS OF THE IMPACT OF POPULATION INCREASE ON THE ECONOMIC GROWTH OF AFRICA'S MOST POPULOUS COUNTRY}

\begin{abstract}
Orji, A., Ogbuabor, J. E., Iwuagwu, Ch., Anthony-Orji, O. I. (2020). Empirical analysis of the impact of population increase on the economic growth of Africa's most populous country. Socioeconomic research bulletin, Vìsnik social'no-ekonomičnih doslìdžen' (ISSN 2313-4569), Odessa National Economic University, Ukraine, No. 2 (73), pp. 27-45.
\end{abstract}

\begin{abstract}
The concern about population growth in many developing countries has become a burning issue in the literature. Furthermore, many divergent views exist on whether increasing population is useful or harmful to growth in the economy. This study therefore, analysed the impact of population increase on economic growth in Nigeria, as an Africa's most populous country. The study employed time series data from 1985-2018 using the framework of the Autoregressive Distributed Lag (ARDL) Model. The findings of this study revealed that the population growth of the economy supports economic growth both in the short and long term. However, it may become explosive in the long run if vital measures are not taken to control it. Since population increase has a huge impact on economic growth, the government should take steps to ensure that the population continues to increase the country's growth trajectory by equipping the workforce with the appropriate skills. Therefore, to enhance sustainable development, the study proposes to formulate an effective government policy in order to ensure the growing labour force with jobs and modern qualification skills in accordance with the requirements of the labor market and increasing the country's GDP. Also, there is need to formulate effective financial policies and support competitive interest rates in order to improve the economy's savings rate. Effective monitoring of the economy's capital-output ratio should ensure its increase in GDP, and the prohibition of effective state policy should be enacted to maintain stable and non-escalating population growth rate.
\end{abstract}

Keywords: population; growth; labour force; economic growth; ARDL; Nigeria; Africa. 


\title{
ЕМПІРИЧНИЙ АНАЛІЗ ВПЛИВУ ЗБІЛЬШЕННЯ НАСЕЛЕННЯ НА ЕКОНОМІЧНЕ ЗРОСТАННЯ НАЙБІЛЬШ ГУСТОНАСЕЛЕНОЇ КРАЇНИ АФРИКИ
}

\begin{abstract}
Анотація. Занепокоєння зростанням населення в багатьох країнах, щуо розвиваються, стало актуальним питанням у літературі. Крім того, існує багато різних поглядів на те, корисне чи шкідливе збільшення чисельності населення для зростання економіки. Зважсаючи на це, у статті проаналізовано вплив збільшення населення на економічне зростання в Нігерї, як найбільш густонаселеній країні Африки. У дослідженні використано дані часових рядів за період 1985-2018 рр. та модель авторегресії і розподіленого лага (ARDL). Результати дослідження показали, щзо зростання чисельності населення в економіці сприяе економічному зростанню, як у короткостроковій, так $i$ в довгостроковій перспективі. Однак у довгостроковій перспективі воно може стати вибухонебезпечним, якщо не вжити життєво важливих заходів для його контролю. 3 огляду на те, щуо збільшення чисельності населення має величезний вплив на економічне зростання, уряду варто вживати заходів задля забезпечення того, щоб населення продовжувало збільшувати траєкторію зростання країни, оснащуючи робочу силу відповідними навичками. Отже, для посилення сталого розвитку в дослідженні пропонується сформулювати ефективну державну політику 3 метою забезпечення зростаючої робочої сили робочими місиями та сучасними кваліфікаційними навичками відповідно до вимог ринку праці і збільшення ВВП країни. Крім того, існує необхідність у формуванні ефективної фінансової політики та підтримиі конкурентних процентних ставок з метою підвищення рівня заощаджень в економіці. Ефективний моніторинг співвідномення капіталу та зростання в економіці має забезпечити його збільшення у ВВП, а запровадження ефективної державної політики дозволить підтримувати стабільні та не ескалаційні темпи приросту населення.
\end{abstract}

Ключові слова: населення; приріст; робоча сила; економічне зростання; ARDL; Hizерія; Африка.

\section{ЭМПИРИЧЕСКИЙ АНАЛИЗ ВЛИЯНИЯ УВЕЛИЧЕНИЯ НАСЕЛЕНИЯ НА ЭКОНОМИЧЕСКИЙ РОСТ НАИБОЛЕЕ ГУСТОНАСЕЛЕННОЙ СТРАНЫ АФРИКИ}

\begin{abstract}
Аннотация. Обеспокоенность ростом населения во многих развивающихся странах стала актуальным вопросом в литературе. Кроме того, существует много различных взглядов на то, полезно или вредно увеличение численности населения для роста экономики. Поэтому в статье проанализировано влияние увеличения населения на экономический рост в Нигерии, как самой густонаселенной стране Африки. В исследовании использованы данные временных рядов за период 1985-2018 г2. и модель авторегрессии и распределённого лага (ARDL). Результаты исследования показали, что рост численности населения в экономике способствует экономическому росту, как в краткосрочной, так и в долгосрочной перспективе. Однако в долгосрочной перспективе оно может стать взрывоопасным, если не принять жизненно важных мер по его контролю. Учитывая, что увеличение численности населения имеет огромное влияние на экономический рост, правительству следует принимать меры для обеспечения того, чтобы население продолжало увеличивать траекторию роста страны, оснащая рабочую силу соответствующими навыками. Итак, для усиления устойчивого развития в исследовании предлагается сформулировать эффективную государственную политику с иелью обеспечения возрастающего количества рабочей силь рабочими местами и современными квалификачионными навыками в соответствии с требованиями рынка труда и увеличения ВВП страны. Кроме того, существует необходимость в формировании эффективной финансовой политики и
\end{abstract}


поддержке конкурентных процентных ставок с целью повышения уровня сбережений в экономике. Эффективный мониторинг соотношения капитала и роста в экономике должен обеспечить его увеличение в ВВП, а внедрение эффективной государственной политики позволит поддерживать стабильные и не эскалачионные темпы прироста населения.

Ключевые слова: население; прирост; рабочая сила; экономический рост; ARDL; Нигерия; Африка.

JEL classification: E600; F430; J100; O400; Q560

DOI: https://doi.org/10.33987/vsed.2(73).2020.27-45

\section{Introduction and motivation of the study}

Sustaining economic growth is an important objective in every economy. It is a macroeconomic objective which every nation wishes to achieve. Economic growth is an increase in the real per-capita income of any nation over a successive period of time. Growth occurs when an economy produces additional goods and services as a result of its increased productive capacity. It talks about the ability of a nation to generate and sustain annual change in its Gross National Product at a rate between 5-7\% (Ogunjiri, 2012).

However, economic growth is said to be mainly affected by population of a nation. Rapid population growth in most developing nations have been said to either be boosting or thwarting government efforts to sustain economic growth. One of such theories that explain the negative effect on population growth is known as the Malthusian Theory which postulates that an increase in population growth thwarts the economic growth of a nation which is quite glaring in developing countries. It was a theory created by Thomas Malthus in his book "An Essay on the Principles of Population" published in 1798. The Endogenous growth theory, on the other hand, believes that population growth would lead to economic growth on the condition that the government develops its human capital. An increase in population of an economy has its pros and cons. An increase in population means an increase in the demand for goods and services which therefore translates to an increase in the economy's GDP. It also implies an increase in labour force of an economy. It would also lead to an increase in dependency ratio as the working section of the population would have to cater for the needs of the dependent (or non-working) part of the population. Also, it could lead to a decrease in per capita income as more individuals reduce the income. It could lead also to a change in the production pattern as producers would shift into the production of those goods and services that would fit the population structure.

Population growth can be seen as the change in the population of an economy. It could be a negative or a positive change. It is negative when there is a decrease in the number of the population while it is seen as positive when there is an increase. The change in this population could also have either a positive or a negative effect on the nation's GDP. A nation's GDP may be experiencing a slower increase even if the population increases significantly while the GDP of another nation might be on the increase even with a lesser increase in its population. This could be because of the human capital development of that country. For the context of this study, we will be focusing on an increase in population. 
Most theories postulate that population growth could be gainful or impeding to the nation's economic growth. One of such theories that explain the detrimental nature of population growth can be traced to the Malthusian theory of 1798 as postulated by Thomas Malthus. Thomas Malthus, in his theory, believed that a rising population growth affects the natural endowment as well as the agricultural produce of the nation in consideration. Kuznets (1956) as well as Boserup (1981) and Simon (1981), on the other hand, explained the beneficial nature of population growth tracing this to the fact that it leads to increase in productivity, increase in economies of scale etc.

The world population has been on the increase over the years. This increase is brought about by the rise in population of various countries. The Nigerian economy is not left out in this increase. At the point when Nigeria pronounced its independence, it was a relatively small nation with just 45.2 billion people. As indicated by the information from the Nigeria Health Watch, Nigeria had tripled over the past 56 years. In 2015, Nigeria had more than 182.2 billion individuals. Today, this number has expanded to over 200 billion individuals (UN, 2019). Different international organisations such as World Health Organisation (WHO) are of the supposition that Nigeria will soon be the third most crowded nation on the planet. Nigeria's population is one of the fastest growing populations on the planet and she is the seventh most populated nation in the world (World Population Data Sheet, 2016). The vast population of Nigeria infers a substantial market for merchandise and ventures and in addition a huge pool of human resource for social and economic improvement. In any case, the effect of population on improvement depends irrefutably on the size as well as on its quality. The significant reason for such increment can be traced to the fact that on the average, the fertility rate is 6.0 life - birth per lady as realised in a study carried out in the 1990s (Nigeria Health Watch, 2016).

According to World Bank (2019), Nigeria's population grows at an average of $2.6 \%$ every year. When compared to the average RGDP growth rate of Nigeria which has been fluctuating over the years, there is a great disparity. Nigeria's population grew at $2.7 \%$ in 1981 but it experienced a negative RGDP of $-13.12 \%$. The country continued to have a negative RGDP from 1981 to 1987 even with an average population growth rate of $2.6 \%$. Though the economy began to enjoy a positive RGDP that was greater than her annual population growth rate, she eventually suffered a negative RGDP of $-0.3 \%$ in 1995 when she was considered to be carrying out a budget surplus. In 2015, the economy had an average growth rate of $2.6 \%$ which was equal to her population growth rate of $2.6 \%$.

Table 1

Annual Growth Rate of Population and GDP (\%) between 2011 and 2018

\begin{tabular}{|l|c|c|c|c|c|c|c|c|}
\hline \multicolumn{1}{|c|}{ Year } & 2011 & 2012 & 2013 & 2014 & 2015 & 2016 & 2017 & 2018 \\
\hline Population & 2.68 & 2.68 & 2.68 & 2.66 & 2.65 & 2.63 & 2.61 & 2.59 \\
\hline GDP & 5.31 & 4.23 & 6.67 & 6.31 & 2.65 & -1.62 & 0.80 & 1.94 \\
\hline
\end{tabular}

Source: World Bank (2019)

However, high population rate could also give rise to an increase in labour supply needed to carry out productive activities in order to sustain economic growth but this can only be possible considering the employment rate of this population. Unfortunately, irrespective of the increase in population in the Nigerian economy, economic growth has been on the increase as shown in Table 2. 
Table 2

ER (economic growth) and LF (labour force) between 2008 and 2017

\begin{tabular}{|c|c|c|c|c|c|c|c|c|c|c|}
\hline Year & 2008 & 2009 & 2010 & 2011 & 2012 & 2013 & 2014 & 2015 & 2016 & 2017 \\
\hline ER & 7.2 & 7.2 & 7.3 & 7.3 & 7.6 & 7.10 & 4.8 & 4.3 & 5.00 & 5.50 \\
\hline LF & 54.86 & 54.91 & 54.96 & 55.01 & 55.06 & 55.10 & 55.09 & 55.10 & 55.15 & 55.15 \\
\hline
\end{tabular}

Source: Index Mundi (2017)

The table above measures economic growth (ER) as a percentage of labour force and Labour force (LF) as a percentage of total population. According to World Bank (2018), Nigeria's total labour force was at 58 billion in 2017 which was $55.15 \%$ as a percentage of its total population. Irrespective of the high labour force rate, the economic growth has been on an increase as it recorded $4.3 \%$ as at 2015 and 5.50 as at 2017. Even with the abundance of cheap labour in the economy, a majority of this labour is unproductive. Against this background, the objective of this article is to empirically investigate the relationship between population growth and economic growth in the Nigerian economy. The rest of this article is structured as follows: Section 2 looks at the literature review, while section 3 is the methodology. The results and discussion are presented in section 4 , while section 5 concludes the article.

\section{Review of relevant literature}

\subsection{Theoretical literature}

\section{Neoclassical growth theory}

The neoclassicals just like the classicalists believe in a free market. They kick against every form of government participation and embrace every form of liberalisation. They believe that the market should be left in the hands of the capitalists and government intervention should be minimal. Government only intervenes when it would be to the benefit of the market.

The basic model under the neoclassical theory is the Solow-Swan model which is simply called the Solow model. This model was developed in 1956 by two economists, Robert Solow and T. W. Swan. This model lays emphasis on savings, investment and population growth as important determinants to economic growth. This theory believes that economic growth is as a result of increase in quantity and quality of labour (this explains population growth and human capital development), increase in capital (this occurs through savings and investment), and improvements in technology.

According to this school of thought, economic growth can be boosted by increase in population and also through human capital development. They are of the belief that an increase in population translates to an increase in labour force which ultimately means an increase in output which leads to an increase in the size of the domestic market. To them, to increase such output faster, the ever-increasing population must be well qualified; this means that the quantity of the population is not enough. It might be a necessary condition but it is definitely not a sufficient condition. The sufficient condition is producing a quality population which is usually carried out through knowledge acquisition.

\section{Endogenous growth theory (New Growth Theory)}

This theory emphasizes on the fact that growth in an economy is as a result of its endogenous (internal) activities. It emphasises on technological progress and human 
capital as a means of boosting output. This theory believes that the differences in per capita income among different countries are as a result of the differences in human capital possessed by these countries. To the new growth theorists, human capital is a factor of production which influences growth.

Unlike the classicalists that believe in only physical stock of capital, the neoclassic and the endogenous growth theories believe that the stock of capital in any economy could be maybe up of both human and physical capital because both influences growth. To the new growth theorists, a higher stock of human capital would imply a higher innovation rate which leads to growth rate of productivity and output growth.

\section{Harrod-Domar Theory}

This theory focuses on the level of savings and the productivity of investment as the determinants of growth in any economy. It was developed by Roy Harrod and Evsey Domar. According to this model, three form of growth exists in every economy. They are the warranted growth which is the rate at which the economy does not expand indefinitely, the actual growth which is real increase in a country's GDP, and finally the natural growth which is the growth that an economy requires to maintain full employment. This theory believes in an unbalanced form of growth.

\section{Coale-Hover Theory}

This is an expansion of the Harrod-Domar theory postulated by Ansley Coale and Edgar Hoover explaining the effect of population growth, productivity of investment and savings rate in low-income countries. This model assumes that as population growth rate raises, the average propensity to save (APS) falls and the incremental capital-output ratio (ICOR, a measure of inefficiency) increases which invariably reduces the growth rate of GDP.

\section{Malthusian Theory of Population}

This theory was proposed by Thomas Malthus in his book "An Essay on the Principles of Population" published in 1798. Thomas Malthus was a British economist and was the first to propose a systematic theory to population. He based his findings on the British economy of that time and proposed in his principles that human population growth rate was increasing at a geometric population while food production was increasing at an arithmetic progression.

His findings on population growth have been divided into three major phases. They include:

- Phase One: For millennia, birth and deaths rates have been very high and of similar magnitudes, yielding extremely low population growth.

- Phase Two: Death rates started declining thanks to better health practices and increases in agricultural and industrial productivity; with first steady birth rates and then demographic inertia due to the age structure, this caused population to explode in Europe in the $19^{\text {th }}$ century and in the developing world in the mid- $20^{\text {th }}$ century.

- Phase Three: With declining birth rates and an aging population, birth and death rates again converge to a low-level equilibrium already reached by developed countries while developing countries are either in the second or at the beginning of the third phase. 


\section{Optimum Transition Theory}

This theory, propounded by Edwin Cannan in his book "Wealth" published in 1924 and popularized by Robbins, Dalton and Carr-Saunders, concerns itself between population size and wealth creation.

The definition of optimum population as given by Edwin Cannan is an ideal population which when combined with the other available resources or means of production of the country will yield the maximum returns or income per head.

However, Robbins, Dalton, and Carr-Saunders have each given this theory their own definitions.

- Robbins defined the theory of optimum transition as the best population which makes the maximum returns gotten in an economy possible.

- Dalton defines it as the population which gives the maximum income per head.

- Carr-Saunders defines it as the population which produces the maximum economic welfare.

From the definitions given above, it can be clearly seen that each of these economists are basically concerned with the maximum benefit of the economy as it concerns population. But the more scientific and realistic view is the view as given by Dalton.

This theory, just like other theories, is based on certain assumptions. These assumptions include: time.

- The economy has a certain amount of natural resources that may change over

- The techniques of production adopted by this economy are constant.

- Constant stock of capital.

- The preferences and habits of the citizens of that economy don't change.

- Even with a $\mathrm{n}$ increase in population, the ratio of the working population to the total population remains constant.

- No change in the working hours of the population.

- Constant organisation of business.

These assumptions explain that ceteris paribus, an increase in the optimum population of the economy would lead to a reduction in the income per head.

\section{Neo-Malthusian Theory}

This theory follows from the Malthusian theory as proposed by Thomas Malthus. This theory explains the expansion of the population following a limited supply of food; but, it also adds to this postulation increase in pollution as a result of the expansion in the population, increase in the technology, a fast decline in the mineral resources of the economy, and the limited capacity of the earth. This theory explains that coupled with the rapid increase in the population rate of the world in general, pollution and industrial development is on the increase thereby reaching the limit of the carrying capacity of the planet.

\subsection{Empirical literature}

Several empirical studies have also been carried out to underscore the relationship between population and economic performance. For example, Ali et al. (2013) analysed 
the impact of population growth and economic growth in Pakistan. The study used the Autoregressive Distributed Lagged (ARDL) Model to investigate the long run relationship between population and economic development for the period of 1975-2008. The study found that population growth impacts positively on economic growth. Though the model explained that vast increase in population growth poses a serious problem for the government as it causes the problem of increase unemployment when viewed indirectly, it leads to economic growth when viewed from a direct impact. This analysis differs from that of Afzal who carried the same research in the same country in 2009. Afzal got an opposite result as he claimed that population growth impacts on economic growth negatively.

Wesley (2017) studied the relationship between population growth and economic growth in Low population growth high-income countries and high population growth low-income countries. The study made use of different variables collected over the past 200 years. It found that low population growth that occurs in high-income economies is likely to create socio-economic problems while high population growth occurring in low-income countries may slow the economic development of such economies. Koduru (2016) in his research on the effect of population growth rate on economic development in India realised that population growth has a positive and significant relationship with economic development such that a rise in population would lead to a rise in economic development. Population growth, economic growth, corruption index, foreign direct investment and natural resource depletion were used as the independent variable while economic development proxied as real gross domestic product stood as the dependent variable.

Also, Abdullah, Shah, Sargani, Ali and Siraj (2015) used ARDL model to study the impact of population growth on economic growth for Bangladesh using data from 1980 to 2005. The study indicates that economic growth and population possess a negative and statistically significant relationship. It concludes that family planning programs to should be used by the government to overcome the negative consequences of her rapidly increasing population. Again, Thuku, Gachanja, and Almadi (2013) studied the impact of population growth on economic growth in Kenya. The study used the Vector Auto Regression estimation technique to analyse the data that spans between the periods 1963 to 2009. It revealed that population growth and economic growths have a statistically significant and positive relationship. It concludes that the population growth in Kenya promotes economic development.

Akintunde, Philip and Oladeji (2013) examined the effect of population dynamics (mortality and fertility) on economic growth in sub- Saharan Africa using the five-year average between the periods of 1970 to 2005. The study, which involves thirty-five countries in the sub-Saharan Africa, used the pooled ARDL and the dynamic panel data analysis to estimate the model. It revealed a negative relationship between total fertility rate and economic growth, and a positive relationship between life expectancy at birth and economic growth. It concluded that the region in view needs to address the problems and consequences of high population growth in order to enjoy sustainable economic development.

Furthermore, Anudjo (2015) carried out a research to check the long and short run relationship between population growth and economic growth in Ghana. The study which employed the ARDL model found out that there exists a negative but significant relationship between population growth and Economic growth. It also found that a 
unidirectional relationship existed between population growth and economic growth. It concluded that the government needs to create policies that would work on family planning hence boosting economic growth. Thuku, Paul and Almadi (2013) in their research investigated the impact of population change on economic growth in Kenya. They study realised that a population growth and economic growth are positively correlated. It employed the Vector Auto Regression estimation technique to carry out such test.

Domestically, few studies have also investigated this relationship but with conflicting results and relatively old data. For example, Adediran (2012) analysed the effect of population growth on economic development in Nigeria. The study found that population growth has a significant and positive relationship with economic growth of Nigeria. The study used the real GDP and Per Capita income (PCI) as proxies for economic development and population growth respectively. Also, Eli, Mohammed, Amade (2015) conducted a research on the impact of population growth on economic growth in Nigeria from 1980 to 2010. The data were analysed using both qualitative and quantitative statistics. The variables of interest were real gross domestic product (RGDP), population growth rate, crude death rate, life expectancy at birth, and export growth rate. The result revealed that a positive relationship exists between economic growth (proxied by GDP growth) and population growth rate.

In another research carried out by Nwosu, Dike and Okwara (2014), he used time series data spanning through 1960 to 2008 to investigate the role of population growth on economic growth in Nigeria and how economic growth is affected through population growth. This study employed a linear model to analyse economic growth fluctuations against population growth and Granger Causality method to check the causal relationship that existed between the two core variables. The study found the existence of a sustainable long run equilibrium relationship between economic growth and population growth, and also a unidirectional causality relationship between population growth and economic growth.

Summarily, this study, unlike other reviewed literatures which evaluated the impact of population increase on economic growth with variables such as population structure, investment, fertility rate, real gross domestic product, etc., would make use of the CoaleHoover Model hence introducing Incremental Capital-Output Ratio (ICOR) to the estimation of the impact of population increase on economic growth in Nigeria. This study would recommend adequate policy options to the government based on the result of its finding, and also add to the global literature in this context.

\section{Data and methodology}

\subsection{Theoretical Framework}

The theoretical framework of this model is based on the Coale-Hoover Growth Model which assumes as population growth rate rises, the average propensity to save (APS) falls and the incremental capital-output ratio (ICOR, a measure of inefficiency) increases which invariably reduces the growth rate of GDP. The model is thus

$$
G\left(\frac{Y}{P}\right)=G(Y)-G(P)
$$




$$
\begin{gathered}
G(Y)=\frac{A P S}{I C O R} \\
G\left(\frac{Y}{P}\right)=\frac{A P S}{I C O R}-G(P)
\end{gathered}
$$

From the equation above, $\mathrm{G}(\mathrm{Y})$ represents the growth rate of GDP of the economy while $\mathrm{G}(\mathrm{P})$ represents the growth of the population. Therefore, $G\left(\frac{Y}{P}\right)$ represents the growth rate of the GDP per capita.

Coale and Hoover believed an increase in the number of children produced in the economy causes a larger fraction of a household's income to be spent on consumption therefore leading to a decline in the savings of the household. Therefore, a rise in population growth rate $(\mathrm{G}(\mathrm{P})$ ) would lead to a decline in average propensity to save (APS). Thus, causing a decline in GDP growth rate $(\mathrm{G}(\mathrm{Y}))$.

Coale and Hoover also believed that increased population would cause the society to spend more of their investment on housing, new schools, medical facilities etc. according to them, the productivity on these investments would be quite lower than the productivity on factories, roads etc. thus ICOR, which represents inefficiency, would rise as the growth rate of the population rises which would eventually reduce the GDP growth rate.

\subsection{Model specification}

The main thrust of this work is to ascertain the impact of population increase on economic growth in Nigeria. To achieve this goal improving upon the theoretical postulate of Coale and Hoover, the empirical model for this study can be expressed functionally as:

$$
\text { LRGDP = } \mathrm{f}(\text { POPGR, LF, LGDS, LGCF, LICOR) }
$$

Econometrically, the equation can be expressed in its linear form as:

$$
\mathrm{LRGDP}=\beta_{0}+\beta_{1} \mathrm{LPOP}+\beta_{2} \mathrm{LF}+\beta_{3} \mathrm{LGDS}+\beta_{4} \mathrm{LGCF}+\beta_{5} \mathrm{ICOR}+\mu
$$

Where:

$\mathrm{L}=$ Log operator.

RGDP: Real Gross Domestic Product.

POPGR: Population Growth Rate, and $\beta_{1}$ coefficient of POPGR.

LF: Labour force, and $\beta_{2}$ coefficient of LF.

LGDS: Log of Gross Domestic Savings, and $\beta_{3}$ coefficient of LGDS.

LGCF: Log of Gross Capital Formation, and $\beta_{4}$ coefficient of LGCF.

ICOR: Incremental capital-output ratio, and $\beta_{5}$ coefficient of ICOR.

$\beta_{0: \text { intercept. }}$

$\beta_{1,} \beta_{2}, \beta_{3}, \beta_{4,}, \beta_{5}$ : parameters.

$\mu$ : Error term. This variable is also called the stochastic or disturbance term. It is contains unobserved factors that affect the model. 
The study adopts ARDL and ARDL-Bounds test because unlike the Ordinary Least Square Model (OLS), it checks for both the long run and short run impacts in the model and it does not consider the problems arising from the different order of integration of the variables amongst other advantages.

In view of these advantages, the ARDL model is expressed thus

$$
\begin{aligned}
\Delta L R G D P_{t}=\alpha_{0} & +\sum_{i=0}^{L} \alpha_{1 i} \Delta L R G D P_{t-1}+\sum_{i=0}^{m} \alpha_{2 i} \Delta L P O P_{t-1}+\sum_{i=0}^{n} \alpha_{3 i} \Delta L F_{t-1} \\
& +\sum_{i=0}^{o} \alpha_{4 i} \Delta L G D S_{t-1}+\sum_{i=0}^{q^{2}} \alpha_{5 i} \Delta L G C F_{t-1}+\sum_{i=0}^{n} \alpha_{6 i} \Delta I C O R_{t-1} \\
& +\beta_{1} L R G D P_{t-1}+\beta_{2} L P O P_{t-1}+\beta_{3} L F_{t-1}+\beta_{4} L G D S_{t-1}+\beta_{5} L G C F_{t-1} \\
& +\beta_{6} I_{C O R_{t-1}}+\mu
\end{aligned}
$$

With this approach, the model can take any maximum number of lags needed to capture its modelling framework.

From the equation (3.3) above, the terms with the summation signs and $\alpha$ are the short run ECM dynamic coefficients while the terms with the $\beta$ are the long run dynamic multipliers. While $\alpha_{0}$ and $\mu$ represent the constant and the error terms respectively. The first difference operator is represented with $\Delta$ while the alphabets $l$ to $q$ represents the lag lengths for the ECM.

To estimate this model, three steps are going to be taken. Firstly, the long run relationship would be estimated. The ARDL Bounds test would be used to ascertain the cointegration among the variables. While conducting this test, if the F-statistics is lower than the lower boundary, there is no cointegration. There is co-integration if the F-statistics is higher than the upper boundary while the test is inconclusive if the F-statistics is higher than the lower boundary but higher than the upper boundary.

The second step is to estimate the long run model using the lag lengths of the ECM below

$$
\begin{aligned}
\Delta L R G D P_{t}=\alpha_{0}+ & \beta_{1} L R G D P_{t-1}+\beta_{2} L P O P_{t-1}+\beta_{3} L F_{t-1}+\beta_{4} L G D S_{t-1}+ \\
& \beta_{5} L G C F_{t-1}+\beta_{6}{I C O R_{t-1}}_{t}+\mu
\end{aligned}
$$

Finally, the short run parameters would be obtained by estimating the ECM associated with the long-run estimates. The model is specified below

$$
\begin{aligned}
\Delta L R G D P_{t}=\alpha_{0} & +\sum_{i=0}^{L} \alpha_{1 i} \Delta L R G D P_{t-1}+\sum_{i=0}^{m} \alpha_{2 i} \Delta L P O P_{t-1}+\sum_{i=0}^{n} \alpha_{3 i} \Delta L F_{t-1} \\
& +\sum_{i=0}^{o} \alpha_{4 i} \Delta L G D S_{t-1}+\sum_{i=0}^{q^{2}} \alpha_{5 i} \Delta L G C F_{t-1}+\sum_{i=0}^{n} \alpha_{6 i} \Delta I C O R_{t-1} \\
& +v_{1} E C M_{t-1}+\mu_{t}
\end{aligned}
$$


From the above equation (3.5), ECM represents the error correction term of the short-run dynamic model. The speed of adjustment of the short run model is represented by $\alpha_{\mathrm{i}}$.

\section{Description and justification of variables}

\section{Dependent variable}

- Real Gross Domestic Product (RGDP): Real Gross domestic product (RGDP) is the monetary value of all the finished goods and services produced within a country for a specific time period. It is gotten after provision for inflation has been adjusted. Put simply, RGDP is a broad measurement of a nation's overall economic activity. The economy's inflationary pressure is also reflected in the RGDP because of its monetary attribute. This allows for easy comparison of a country's yearly GDP. This is the dependent variable and Eigbiremolen and Anaduaka (2014) used it to capture economic growth.

\section{Independent Variable}

- POPGR (Population): This is a change in the population size of a country which could be either a positive or negative change. It is said to be positive when there is an increase, and it is negative when there is a decrease in the number of individuals residing in a country. Population growth can also be defined as the average annual rate of change of population size during a specified period. Adeniran (2012) used this variable to carry out a research on the Effect of Population on Economic Development in Nigeria. The study revealed a positive and statistically significant relationship between population growth and RGDP.

- LGDS (Log of Gross Domestic Savings): According to Investopedia (2019), a savings rate is the amount of money deducted by a person from his disposable income that is set aside. It is expressed in percentage or ratio form. The savings rate in Nigeria (proxied by Gross Domestic Savings as a percentage of RGDP) has been fluctuating over the years. There was a 2.44 decline in 2016 as it reduced from 15.49 in 2015 to 13.05 in 2016. Gross Domestic Savings would be used to proxy Savings rate. Aidi et al. (2014) used this variable as a core independent variable investigates the impact of Population dynamics on economic growth in Nigeria. The study realized that a negative but statistically significant relationship existed between savings rate and economic growth.

- LGCF (Log of Gross Capital Formation): Investment is basically used for future returns. It is the purchase of goods for the sole purpose of creating more wealth in the future. The proxy for this variable would be the Goss Capital Formation (GCF). This is because GCF captures fixed assets and change in stocks (inventories). In Nigeria, the GCF as a percentage of RGDP has been fluctuating over the years. It fell to 15.34 in 2016 as against 15.49 of 2015. Aidi et al (2014) used this variable as an independent variable to investigate the impact of Population dynamics on economic growth in Nigeria. The study realised that a positive but non-statistically significant relationship existed between investment and economic growth.

- ICOR (Incremental Capital-Output ratio): This explains how much of capital would be needed to produce one additional unit of output. It determines how efficiently the economy uses its capital to produce a given level of output. 
A lower ICOR is more appreciated to a higher one but low ICOR explains efficiency while a high ICOR explains inefficiency which implies a lower level of capital productivity.

\section{Results and discussion}

We begin by presenting the cointegration test and unit root tests conducted on our variables. This is important to avoid running spurious regression.

\subsection{Pre-estimation Test}

\subsubsection{Unit Root Test}

Cointegration is a statistical property of time series variables which establishes the existence of equilibrium long run relationship between the variables. It also ensures that linear combination or regression of such variables is not spurious. This study employs ADF cointegration test. The summary of the ADF test using AIC criterion is reported in the table below.

Table 4.1

Unit Root Test at 5\% Significance Level

\begin{tabular}{|c|c|c|c|c|c|c|c|}
\hline \multirow[b]{2}{*}{ Variable } & \multicolumn{2}{|c|}{ Level form } & \multicolumn{2}{|c|}{ First difference } & \multicolumn{2}{|c|}{ Second difference } & \multirow[b]{2}{*}{$\begin{array}{c}\text { Order of } \\
\text { integration }\end{array}$} \\
\hline & $\begin{array}{c}\text { ADF } \\
\text { statistic }\end{array}$ & $\begin{array}{c}\mathrm{ADF} \\
\text { critical } \\
\text { value }\end{array}$ & $\begin{array}{c}\text { ADF } \\
\text { statistic }\end{array}$ & $\begin{array}{c}\text { ADF } \\
\text { critical } \\
\text { value }\end{array}$ & $\begin{array}{c}\text { ADF } \\
\text { statistic }\end{array}$ & $\begin{array}{c}\text { ADF } \\
\text { critical } \\
\text { value }\end{array}$ & \\
\hline LGCF & -4.57 & -3.56 & - & - & - & - & $\mathrm{I}(0)$ \\
\hline LRGDP & -2.79 & -3.55 & -4.24 & -3.55 & - & - & $\mathrm{I}(1)$ \\
\hline LGDS & -4.32 & -3.55 & - & - & - & - & $\mathrm{I}(0)$ \\
\hline ICOR & -4.59 & -2.96 & - & - & - & - & $\mathrm{I}(0)$ \\
\hline LF & -2.47 & -3.55 & -4.44 & -3.56 & - & - & $\mathrm{I}(1)$ \\
\hline LPOP & -4.65 & -3.61 & - & - & - & - & $\mathrm{I}(0)$ \\
\hline
\end{tabular}

Source: Authors' computation (E-views 10.1), 2020

In employing the ADF test, this analysis makes use of the $5 \%$ level of significance such that the null hypothesis (there is unit root) is rejected when the ADF test statistics exceeds the ADF critical value at 5\% level of significance. The result above shows that investment (LogGCF), savings (LogGDS), incremental capital-output ratio (ICOR) and population growth (LogPOP) are integrated at level form $(\mathrm{I}(0))$ while economic growth (LogRGDP) and labour force (LogLF) are integrated at order one (I(1)). Therefore, the model is integrated of order zero and one.

\subsubsection{Cointegration Test}

Given that the specified models for this study are mixed equation models, we the ARDL Bounds test. The ARDL Bounds test is employed under the assumption that the series are cointegrated if the calculated F-Statistics is greater than the Critical value at 5\% level of significance. The result is presented in Table 4.2.

The ARDL bounds test was further used to check co-integration. The analysis above shows that the calculated F-statistics (4.23) exceeds the upper bound F-critical value at $5 \%$ level of significance. The result, therefore, supports the rejection of the null 
hypothesis that exist no long run relationship among the variables and therefore concludes that there exists a long run relationship among the variables.

Table 4.2

ARDL Bounds Test

\begin{tabular}{|c|c|c|c|c|c|}
\hline \multirow{2}{*}{$\begin{array}{c}\text { Test } \\
\text { statistic }\end{array}$} & \multirow{2}{*}{ Value } & \multirow{2}{*}{$\mathrm{K}$} & \multirow{2}{*}{$\begin{array}{c}\text { Level of } \\
\text { significance }\end{array}$} & \multicolumn{2}{|c|}{ Critical value bounds } \\
\hline & & & & $\mathrm{I}(0)$ & $\mathrm{I}(1)$ \\
\hline F-statistic & 4.236510 & 5 & $10 \%$ & 2.26 & 3.35 \\
\hline & 4.236510 & 5 & $5 \%$ & 2.62 & 3.79 \\
\hline & 4.236510 & 5 & $2.5 \%$ & 2.96 & 4.18 \\
\hline & 4.236510 & 5 & $1 \%$ & 3.41 & 4.68 \\
\hline
\end{tabular}

Source: Authors' computation (E-views 10.1), 2020

\subsection{Presentation and interpretation of regression results}

\subsubsection{Model estimation and interpretation}

The table below shows the long run estimates of the ARDL model. The result shows a statistically significant relationship amongst most of the variables such as investment (LGCF), labour force (LLF), and population growth rate (LPOP).

Table 4.3

The Long run ARDL Results

\begin{tabular}{|c|c|c|c|c|}
\hline Variable & Coefficient & Std. Error & t-Statistic & Prob. \\
\hline LGCF & 0.197785 & 0.074399 & 2.658446 & 0.0135 \\
\hline LGDS & 0.037519 & 0.032978 & 1.137690 & 0.2660 \\
\hline LLF & -8.781646 & 2.394835 & -3.666911 & 0.0012 \\
\hline ICOR & -0.000202 & 0.000748 & -0.270447 & 0.7890 \\
\hline LPOP & 10.178901 & 2.466533 & 4.126805 & 0.0004 \\
\hline C & -5.181680 & 2.439711 & -2.123891 & 0.0438 \\
\hline R-squared $=0.992770$ & \multicolumn{3}{|l|}{ Prob(F-statistic $)=0.000000$} \\
\hline
\end{tabular}

Source: Authors' Computation (E-views 10.1), 2020

From the table above, $\mathrm{R}^{2}$ is 0.992770 which implies that the model explains about $99 \%$ of the total variation in economic growth (LGDP). The coefficient (C) is estimated at -5.18 showing a negative relationship between economic growth and population growth, meaning that on the average, without the interference of the independent variables, economic growth is said to decrease by 5.18 percent with a negative and statistically significant t-value of 2.12 .

Investment which is proxied by LGCF is a very important factor in the aspect of entrepreneurship because an increase in savings leads to an increase in investment as individuals are able to use this money to create more job opportunities. From the result above, LGCF has a positive and statistically significant relationship with economic growth as a percentage increase in it causes economic growth to increase by 0.19 percent. Savings, proxied as LGDS, also has a positive relationship with economic growth as an increase in savings by one percent increases economic growth by 0.038 percent. Unfortunately, this relationship cannot be given much credence as it is seen to be 
statistically insignificant. This could be attributed to the poor savings culture of citizens in the economy and the economy in general.

Labour force which is the backbone of every economy is negatively but statistically significant to Nigeria's economic growth. The negative relationship can be as a result of the low human capital development evident in the nation. Therefore, with an increase in labour force, there is also an increase in the number of individuals who are not well qualified to play a valid role in the production process causing economic growth to decline by 8.78 percent when labour force increases by one unit.

The coefficient of population (LPOP) is positive and statistically significant to economic growth depicting that with an increase in population by one percent, economic growth would increase by 10.17 percent. Nevertheless, ICOR has a negative and statistically insignificant relationship with economic growth as its one percent increase causes economic growth to decrease by 0.000202 percent. This could be as a result of the fact that employers tend to shift from labour-intensive form of production to capital-intensive when means of credit which causes increase in capital is readily available. This shift causes more individual to be unemployed thereby reducing the employment rate in the economy.

\section{Table 4.4 The ARDL-ECM result}

In order to ascertain how the variables, adjust to long run equilibrium through short run dynamics, the error correction model was estimated. The result of the error correction model (ECM) is shown on Table 4.4.

Table 4.4

Error Correction Model Estimates

\begin{tabular}{|c|c|c|c|c|}
\hline Variable & Coefficient & Std. Error & t-Statistic & Prob. \\
\hline D(LOGGCF) & 0.094974 & 0.051296 & 1.851486 & 0.0759 \\
\hline D(LOGGDS $)$ & 0.018016 & 0.014553 & 1.237992 & 0.2272 \\
\hline D(LOGLF) & -4.216850 & 1.247880 & -3.379212 & 0.0024 \\
\hline D(ICOR $)$ & -0.000097 & 0.000363 & -0.267622 & 0.7912 \\
\hline D(LOGPOP) & 4.887797 & 1.372179 & 3.562069 & 0.0015 \\
\hline ECM & -0.480189 & 0.120932 & -3.970721 & 0.0005 \\
\hline
\end{tabular}

Source: Authors' computation (E-views 10.1), 2020

As shown in Table 4.4, the Error Correction Model for economic growth is $-0.48 \%$. This suggests that about $48 \%$ of last quarter's disequilibrium is corrected in current quarter respectively. Hence, when economic growth is above or below its equilibrium level, it adjusts by approximately 48 percent within the first quarter to ensure full convergence to its equilibrium level. In addition, the error correction model (ECM) for economic growth equation is negative and strongly statistically significant. The statistical significance of the negatively signed error correction model (ECM) further lends credence to the co-integration among the variables under investigation. Thus, we conclude that deviations 
in the short run among the cointegrated processes are corrected in the long-run to attain a stable equilibrium.

\subsection{Specification and diagnostic test}

Table 4.5

Specification and Diagnostic Test Estimates

\begin{tabular}{|l|c|c|}
\hline \multicolumn{1}{|c|}{ Test } & Statistic & Value (p-value) \\
\hline Ramsey RESET test & F-statistic & $1.013615(0.3241)$ \\
\hline White heteroskedasticity test & F-statistic & $3.146499(0.0194)$ \\
\hline Breusch-Godfrey LM test & F-statistic & $0.325830(0.7252)$ \\
\hline
\end{tabular}

Source: Regression result estimated using E-views 10.1

The diagnostic test of the model in the table 4.5 above indicates an absence of specification error following the Ramsey reset test while the heteroskedasticity test revealed that the residuals are heteroskedastic. Finally, the Breusch-Godfrey test accepts the null hypothesis of the residuals being serially uncorrelated.

The cumulative sum (CUSUM) test and the Cumulative sum (CUSUM) of squares test were adopted to analyse the model's stability. The results are shown below.

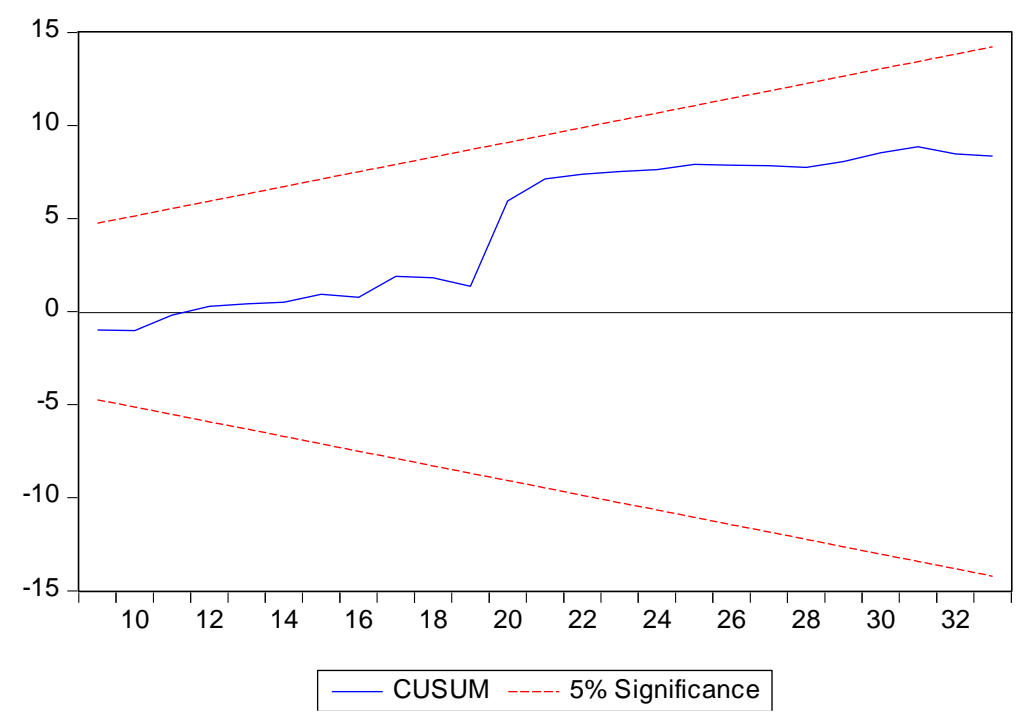

Fig. 1. CUSUM test 


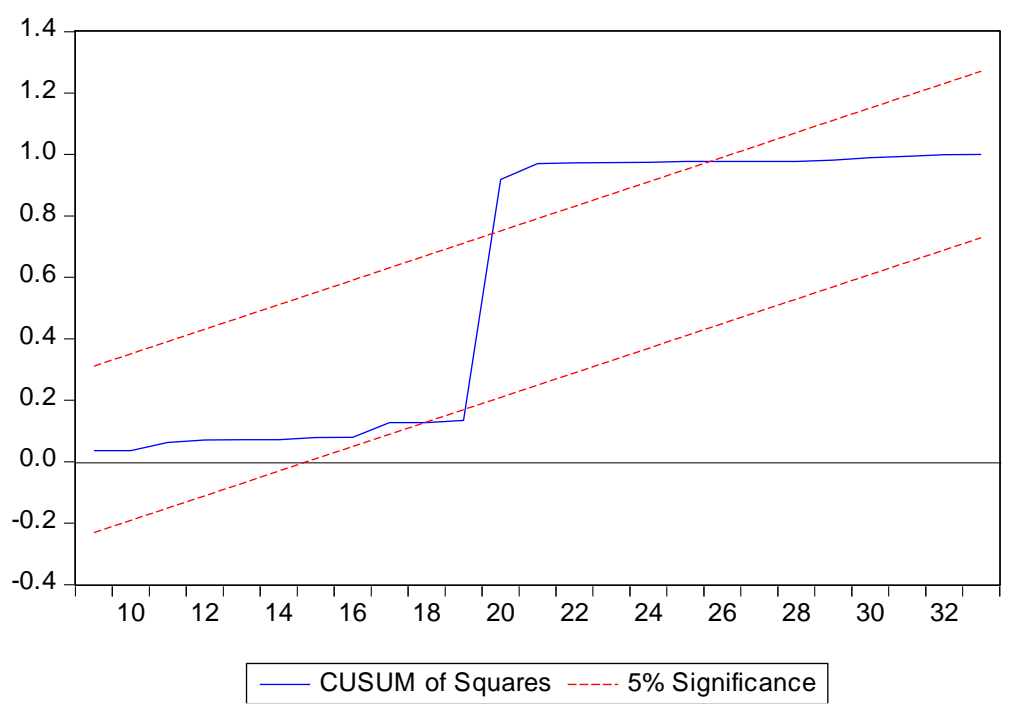

Fig. 2. CUSUM squares test

The figures above are estimated at 5\% level of significance. From these figures, it can be inferred that there is stability in the model for the period under study since the CUSUM did not go outside the critical lines and the CUSUM squares left the line by an inconsequential amount.

\section{Conclusion and policy recommendation}

The aim of this research work is to ascertain the impact of population growth on economic growth in Nigeria from 1985 to 2018. To accomplish this objective, an econometric methodology was adopted as a tool for testing the stated hypotheses. The ARDL (Auto-Regressive Distributed Lagged) Model was chosen because of the merits it has over other models with respect to the phenomenon under study.

The findings of this study revealed that Investment (proxied as LGCF), Savings (proxied as LGDS) and population (proxied as POPGR) have a positive relationship with Economic Growth (proxied as LGDP). Unlike investment and population that are statistically significant, savings is unfortunately statistically insignificant. This result could mean that what is saved is being used as investment which impacts positively on the economy and a rising population increases GDP because it increases the market size of the economy. On the other hand, ICOR and Labour force (proxied as LLF) have a negative relationship with economic growth. On the part of the ICOR, there happens to be inefficiency because a larger percentage of capital is needed to produce the given output in the economy. The nation's labour force seen to be detrimental the growth of the economy might be because there is no reasonable development on the side of her human capital (labour force) therefore, her labour force is made up of a high proportion of uneducated individuals as well as a high level of unhealthy individuals.

Population is a major and sensitive variable that affects the nature of an economy's and as well foster economic growth. High population growth rate without subsequent investment in human capital negatively contributes negatively to the economic growth of an economy (as can be viewed with the nation's labour force). The government should not 
only be involved in curtailing population growth but should also improve the nations productive output with the available resources. This, in a long run, will lead to sustainable economic growth.

In summary, the result revealed that population has a huge impact on economic growth but the government needs to work on the human capital development of its labour force as it is also a very significant determinant of its economic growth. Therefore, to enable sustainable development, the government should: first, formulate effective policies to ensure that the growing labour force are well equipped to add positively to the country's GDP. Second, formulate effective financial policies and support competitive interest rates in order to improve the economy's savings rate. Third, efficiently monitor its capitaloutput ratio to ensure that it adds to its GDP and fourth, maintain stable and nonescalating population growth rate. This is because based on the research for the period, population contributes to the nation's GDP. Thus, measures should be carried out to sensitize people on the pros and cons of increasing population and its effect to the economy in general.

\section{References}

Aidi, H., Emecheta, C., \& Ngwudiobu, I. (2016). Population Dynamics and Economic Growth in Nigeria. Journal of Economics and Sustainable Development, Vol. 7, No. 15, pp. 16-24.

Ali, S., Alam, K., Islam, S., \& Hossain, M. (2015). An Empirical Analysis of Population Growth on Economic Development: A Case Study of Bangladesh. International Journal of Economics, Finance and Management Sciences, Vol. 3, No. 3, pp. 252-259. DOI: 10.11648/ j.ijefm.20150303.21.

Ali, S., Ali, A., \& Amin, A. (2013). The Impact of Population Growth on Economic Development in Pakistan. Middle-East Journal of Scientific Research, Vol. 18 (4), pp. 483-491. DOI: 10.5829/idosi.mejsr.2013.18.4.12404.

Almendarez, L. (n.d.). Human Capital Theory: Implications for Educational Development. Retrieved December 18, 2017, from Open: http://www.open.uwi.edu/sites/default/files/ bnccde/belize/conference/papers2010/almendarez.html.

Anudjo, E. (2015). The Population Growth - Economic Growth Nexus: New Evidence from Ghana. University of Ghana. Retrieved from: http://ugspace.ug.edu.gh/handle/123456789/ 8484 ? show=full.

Barone, R. (2017). The Importance of Economic Growth and the Consequences of its Demise. Retrieved December 21, 2017, from Forbes: https://www.forbes.com/sites/greatspeculations/ 2017/06/09/the-importance-of-economic-growth-and-the-consequences-of-its-demise/\#3c6a $588 \mathrm{a} 3966$.

Coale, A., \& Hoover, E. (1959). Population Growth and Economic Development in Low-Income Countries. The American Economic Review, Vol. 49, No. 3, pp. 436-438.

Esu, G., \& Udonwa, U. (2016). Determinants of Economic Growth in Nigeria: Population Perspective. Journal of World Economic Research, Vol. 5, Issue 4, pp. 31-42. DOI: $10.11648 /$ j.jwer.20160504.12.

Headey, D., \& Hodge, A. (2009). The Effect of Population Growth on Economic Growth: A MetaRegression Analysis of the Macroeconomic Literature. Population and Development Review, Vol. 35, No. 2, pp. 221-248. DOI: https://doi.org/10.1111/j.1728-4457.2009.00274.x.

Ibenegbu, G. (2017). Population Growth in Nigeria. Retrieved December 20, 2017, from Naij.com: https://www.naija.ng/1127784-effects-population-growth-nigeria.html\#1127784. 
J., Y. (n.d.). Population Growth: Demographic Transition and Malthusian Theories. Retrieved December 19, 2017, from Study.com: https://study.com/academy/lesson/population-growthdemographic-transition-and-malthusian-theories.html.

Koduru, C. (2016). Effect of Population Growth on Economic Development in India. Retrieved Feburary 2019, from ResearchGate: https://www.researchgate.net/publication/309158950_ Effect_of_Population_Growth_on_Economic_Development_in_India?enrichId=rgreq-aef3b a74dec3d83dd1e312187fb7a302-XXX\&enrichSource=Y292ZXJQYWdlOzMwOTE1ODk1 MDtBUzo0MTczMDQ4ODMwMjM4NzJAMTQ3NjUwNDY0NTY4Mw\%3D\%3D\&e.

Kwat, N. (n.d.). Top 3 Theories of Population. Retrieved December 19, 2017, from Economics Discussion: http://www.economicsdiscussion.net/theory-of-population/top-3-theories-ofpopulation-with-diagram/18461.

Mahendra, K. (n.d.). Population Growth and Economic Development: A Close View. Retrieved December 20, 2017, from Economics Discussion: http://www.economicsdiscussion.net/ economic-development/population-growth-and-economic-development-a-close-view/11808.

Nwosu, C., Dike, O., \& Okwara, K. (2014). The Effects of Population Growth on Economic Growth in Nigeria. The International Journal of Engineering and Science (IJES), Vol. 3, No. 11, pp. 7-18.

Odusina, E. K. (2010). Implications of a Rapidly Growing Nigerian Population: A Review of Literature. Osun State: Joseph Ayo Babalola University. Retrieved from: https://uaps2011.princeton.edu/papers/110048.

Ogunleye, O., Owolabi, O., \& Mubarak, M. (2018). Population Growth and Economic Growth in Nigeria: An Appraisal. International Journal of Management, Accounting and Economics, Vol. 5, No. 5, pp. 282-299.

Oramah, I. (2006). The Effects of Population Growth in Nigeria. Journal of Applied Sciences, Vol. 6, pp. 1332-1337. DOI: 10.3923/jas.2006.1332.1337.

Preston, S., \& Donaldson, P. (1986). Population growth and economic development. Asia Pac Popul J., Vol. 1, No. 2, pp. 3-12.

Rosenzwig, R. M. (1987, July). Human Capital, Population Growth and Economic Development: Beyond correlation. The University of Chicago Press Journals, Vol. 98, No. 5, pp. 38-70.

Sinding, S. (2009). Population, poverty and economic development. Philos Trans $R$ Soc Lond B Biol Sci, Vol. 364, Issue 1532, pp. 3023-3030. DOI: https://doi.org/10.1098/rstb.2009.0145.

Tartiyus, E., Dauda, M., \& Amade, P. (2015). Impact of Population Growth on Economic Growth in Nigeria (1980-2010). IOSR Journal of Humanities and Social Science (IOSR-JHSS), Vol. 20, Issue 4, pp. 115-123. DOI: 10.9790/0837-2045115123.

Thornton, J. (2001). Population Growth and Economic Growth: Long-Run Evidence from Latin America. Southern Economic Journal, Vol. 68, Issue 2, pp. 464-468.

Thuku, G., Paul, G., \& Almadi, O. (2013). The Impact of Population Change on Economic Growth in Kenya. International Journal of Economics and Management Sciences, Vol. 2, No. 6, pp. 43-60. DOI: 10.4172/2162-6359.1000137.

Wesley, E., \& Peterson, F. (2017). The Role of Population in Economic Growth. SAGE Open, Vol. 7, Issue 4, pp. 1-15. DOI: https://doi.org/10.1177/2158244017736094. 